\title{
CORRIGENDUM
}

\section{Effects of bumetanide on neurobehavioral function in children and adolescents with autism spectrum disorders}

E Lemonnier, N Villeneuve, S Sonie, S Serret, A Rosier, M Roue, P Brosset, M Viellard, D Bernoux, S Rondeau, S Thummler, D Ravel and Y Ben-Ari

Translational Psychiatry (2017) 7, e1124; doi:10.1038/tp.2017.101; published online 9 May 2017

Correction to: Translational Psychiatry (2017) 7, e1056; doi:10. 1038/tp.2017.10; published online 14 March 2017

The ninth author's affiliation was presented incorrectly in the published paper. Additionally, only the first affiliation should have included CHU Hôpital Le Cluzeau. The correct affiliations appear below:

E Lemonnier ${ }^{1}$, N Villeneuve ${ }^{2}$, S Sonie ${ }^{3}$, S Serret ${ }^{4}$, A Rosier ${ }^{5}$, M Roue $^{6}$, P Brosset ${ }^{1}, M$ Viellard ${ }^{2}$, D Bernoux ${ }^{7}$, S Rondeau ${ }^{5}$, S Thummler ${ }^{4}$, D Ravel ${ }^{8}$ and Y Ben-Ari ${ }^{8,9}$

${ }^{1} \mathrm{CHU}$ Hôpital Le Cluzeau, CHU Limoges, Limoges, France

${ }^{2}$ Hôpital Sainte Marguerite, Marseille, France

${ }^{3} \mathrm{CHU}$ le Vinatier, Bron, France

${ }^{4} \mathrm{CHU}$ Lenval, Nice, France

${ }^{5} \mathrm{CHU}$ Le Rouvray, Sotteville les Rouen, France
${ }^{6} \mathrm{CHRU}$ Brest, Brest, France

${ }^{7}$ EPICIME-CIC 1407 de Lyon, Hospices Civils de Lyon, Inserm, Bron, France

${ }^{8}$ Neurochlore Research Team, Marseille, France

${ }^{9}$ Neurochlore Research Team, C/O INMED, INSERM Unité 901, Aix Marseille Université, Marseille, France

This work is licensed under a Creative Commons Attribution 4.0
International License. The images or other third party material in this
article are included in the article's Creative Commons license, unless indicated
otherwise in the credit line; if the material is not included under the Creative Commons
license, users will need to obtain permission from the license holder to reproduce the
material. To view a copy of this license, visit http://creativecommons.org/licenses/
by/4.0/
(c) The Author(s) 2017

